УДК: [821.161.2-3Шевчук.09:821.161.2-3Дрозд.09]:82.091

\title{
«ЙОКНАПАТОФА» ВАЛЕРІЯ ШЕВЧУКА ТА ВОЛОДИМИРА ДРОЗДА ЯК ТОПОС «ВТРАЧЕНОГО РАЮ»: МОДЕЛЮВАННЯ «МАЛОЇ БАТЬКІВЩИНИ»
}

\section{Людмила Броніславівна Тарнашинська}

\author{
https://orcid.id 0000-0003-2540-2658 \\ tarnashynska@gmail.com \\ Доктор філологічних наук, професорка, \\ провідний науковий співробітник Відділу української літератури XX ст. \\ та сучасного літературного процесу, \\ Інститут літератури імені Т.Г. Шевченка НАН України
}

\begin{abstract}
Анотація. У изентрі уваги дослідниці-наративи «малої батьківщцини» (з проекиіями на світову літературу) українських письменників-шістдесятників: житомирський текст Валерія Шевчука та поліський текст Володимира Дрозда - з їхніми топосами, геоментальними моделями, проекціями на «образи свідомості». Йдеться про художню топографію топосів метафоричного наповнення «землі обітованої», «Кастальського джерела», «втраченого раю» (через розгортання вектору сім'я/родина - оселя/дім - вулиця/юрба - околиця/передмістя/ місто, дорога, ключовим у якому є топос дому), які вибудовують модель сприйняття світу й себе у изьому світі.

У фокусі дослідження - художня репрезентаиія національної ідентичності у ї регіональних варіантах як локальної автентичності, спроектованої на візію «великої України» (колективна та індивідуальна ідентичність у їі соціокультурних виявах). Це дає можливість дослідити етно-національні текстові проекції ідентичностей у художньому дискурсі. Простежено, як із допомогою поетики локального простору циим прозаїкам вдалося художньо відтворити візію України у ї̈ розмаїтих часопросторових векторах, спроектувати «колективний портрет» української людини з їі самобутньою ідентичністю.
\end{abstract}

Ключові слова: Йокнапатофа; «втрачений рай»; топоси; житомирський текст; поліський текст; ідентичність.

Хроногеометрія українського шістдесятництва знаходить своє відображення в поетиці, художньо-естетичні координати якої визначаються векторами простір/час, де перше також включає простір внутрішній. Антропний простір/час, укладений шістдесятниками у відповідні топоси (як-то дім, мала батьківщина, чужина та ін.), віддзеркалює зміст буття «тут-і-тепер» або «осьтут-існування» як перехідний, переломний етап людської свідомості, що вивільняється від тоталітарних пут і виходить поза межі самої себе (тобто за межі раніше дозволеного/дозованого). Адже топоси - це ще й ті чи ті факти життя і думки, котрі здатні зробити силогізми переконливими, попри їх матеріальну невідповідність і незрозумілість» [7, с. 26]. Це виразно простежується на прикладі творчості Валерія Шевчука з його підкреслено маніфестованим персонажем околиці невеликого міста (конкретно Житомира) i, скажімо, Володимира Дрозда з його антропологічним виміром українського Полісся.
Ще з раннього періоду своєї творчості В. Шевчук, маючи унікальну здатність репрезентувати своєрідні зразки синтезу засобів художнього мислення, створює власну Йокнапатофу, свою художню «житомирську галактику», сконцентровану на локальній території (фактично це околиці міста Житомира, де народився і виріс письменник), населяючи іiі героями, яких добре знає 3 повсякденного життя. Адже простір «як порядок співіснування $\epsilon$ множинність кореляцій, що структурують інтервали 3 позицій відносин типу околиці, прилягання і т. д.) [4, с.164]. 3 часом письменник дедалі більше розпросторює цей простір, усе щільніше заповнюючи його характерами, колізіями, побутовими реаліями, центральним у якому залишається Шевчукова ідея дому як духовного осердя людини. Маючи хист синтезатора традиційних художніх набутків зі стильовими пошуками прозаїків європейської школи (як-то засад французьких екзистенціалістів, голдінівської манери письма в стилі англій- 
ських притч, засвоєння фолкнерівських прийомів творення власної «художньої галактики», а також тяжіння до «магічного реалізму», химерної прози, що визначає часово-просторові структури латиноамериканського роману) [Див.: 8], В. Шевчук напрацював і розгорнув у своїх творах злагоджену систему топосів. Відповідно до середньовічних універсалізованих уявлень про землю загалом i життя на ній письменник зазвичай вплітає у художній задум описи рідної землі, надто своєї малої батьківщции - через те на сторінках його творів найчастіше знаходимо житомирські пейзажі, фантастичні народні оповідки, а також сьогоденні побутові реалії, що дають уявлення про специфіку та усталений уклад життя сучасного передмістя. Певна універсалізація описів природи виправдана авторським намаганням звести іiі до рівня філософської категорії, метафори, тобто універсального, синтетичного образу. Послуговуючись бароковим інструментарієм творення універсальної картини світу, прозаїк зазвичай іде від часткового до образу цілого (й навпаки: знаходить часткове в цілому), прикладом чого є витворення локальної місцевості, житомирської околиці, яка розгортає Шевчукову візію України (тобто цілісний образ через часткове, свідомо локалізоване). Тому в описах житомирських околиць (чи то берегів ріки, чи то вуличок та приміських кварталів), вгадується загальне «обличчя» всієї України.

Для прози Шевчука наскрізним залишається вузол проблем, що формують апологію дому з широким розгалужсенням відповідних топосів, що визначають зв'язок людини та їі родоводу. Поетика будня, що їі активно апробує письменник, принесла з собою й реабілітувала (після репресивних інтенцій тоталітаризму) таку лакуну, як приватність людського життя. На «території» топосу будня у свій спосіб прирощується людський дух, набирають сенсу нібито незначні, навіть другорядні, а насправді сутнісні речі, як, скажімо, поглиблена рефлективність. У цьому просторі приватного особливо помітний «Роман юрби. Хроніка «безперспективної» вулиці (1972-1991)», побудований за принципом своєрідної саги (в даному випадку напрошується означення, цілком нове для української літератури, - вуличної саги з їі наскрізним топосом вулиці). Події, локалізовані в просторі цього топосу, де все пов'язано між собою видимими й невидимими нитями, взаємозалежне/взаємоопромінене емоціями, енергетиками чужих душ/думок/ учинків, які найповніше відлунюють саме в топосі околиці. Цей роман із його концептуальною назвою несе потужне смислове навантаження, адже розгортає також наповнені особливим сенсом топоси, що антропологізують художній простір письменника. Так, у своєму автобіографічному творі «На березі часу» В. Шевчук, зокрема, порушує проблему: юрба - індивідуальність, яка здавна його хвилювала. Саме соціоантропологічне окреслення хроноmony, маркованого топосом «юрба» (як наголошує В. Шевчук, це поняття в українській літературній мові веде свій «родовід» від «Енеїди» П. Котляревського; його ж вразило тією сугестивною силою, що ii вклала в нього Леся Українка при аналізі творів В. Стефаника) вказує на спів-дію в одному просторі багатьох індивідуальних «Я». Шевчуків monoc юрби вказує не на натовп, який сприймає реальність на рівні масової свідомості, інфікованої вождизмом і фанатизмом, а швидше - mоnocy юрми: як багатолюддя, багатоголосся, (власне, це та поліфонія, яку М. Бахтін визначає головною передумовою будь-якого роману), де вирізняється окремий індивідуальний голос, який репрезентує окремішню свідомість.

Шевчукові герої зазвичай мають власний дім на околиці як місце для осідку й гармонії, бо міські, «інкубаторні» форми буття для них неприйнятні. Цей особливий тип мешканця околиціi/nередмістя (і ці топоси треба також розрізняти) зі своїм специфічним психологічним комплексом найчастіше стає об'єктом художньої обсервації письменника. Міфологізуючи так звану «маленьку людину», яка борониться від ворожого їй світу у своєму домі (однак повсякчас відчуваючи й «прокляття світу в собі») письменник наповнює цей наскрізний топос цілою мережею співзалежних топосів, які розгортають, поглиблюють смислами й конкретизують деталями/станами наскрізний.

Будь-які роздуми про апологетику дому у творчості В. Шевчука повертають нас у минуле, явлене романом-преамбулою «Дім на горі», що викликає уявлення про усталений уже топос дому як місця людського самовизначення 3 його потужною енергетикою роду/poдоводу, «запатентованого» цим письменником в історії української літератури в другій половині ХХ ст. Кидаючи потужний відсвіт на всю подальшу творчість, цей твір залишається метафорою багатозначності топосу «дім» - передусім як «обителі духу». Апологія рідного дому, якою перейнята творчість письменника, чи не най- 
більше проявляється через образ провінційного поета Сильвестра («Білецькі»: роман «Стежка в траві»): саме він актуалізує метафоричний топос стежки в траві як символу ідеалу. Уже «пізній» В. Шевчук, захоплений можливістю побачити будинок «як живу істоту», антропологізує архетип дому, наділяючи (топологізуючи) його людськими властивостями. Роман «Привид мертвого дому» також розгортає метафору дому, яка, однак, несе інше смислове навантаження. Тема людської оселі постає тут у новій для письменника іпостасі як топос «мертвого дому»: дім сфокусовує в собі минуле й теперішнє, проектуючись на майбутнє як можливість (чи неможливість) самореалізації людини. При цьому сам топос дому набуває різних статусних інваріантів: як прихисток (притулок), як фортеия (захист від навколишнього, зчаста непривітного світу), як власний «острівещь щзастя» (або його антиподів), як «вежа приватності», як своєрідна «лабораторія» міжлюдських стосунків, зрештою, дім як «рай» або «пекло», як храм чи «земля обітована», відвойована у «ворожого» простору. Але завжди - як осердя, носій «автентичної подоби людини» і водночас як «внутрішній диктат» $\mathrm{i}$ «рушій» iï вчинків (Р. Мовчан).

Фактично в прозі В. Шевчука вибудовується соціовекторний ланцюжок антропологічних топосів обсервованого письменником повсякдення: сім'я/родина - оселя/ дім - вулиия/юрба - околиия/передмістя/ місто, дорога, ключовим у якому є топос дому. Топоси дому/вулииі/околииі - найяскравіші складові соціуму, його найточніше віддзеркалення, бо тільки в тісних міжлюдських стосунках індивідуум проявляє себе повною мірою, наближається до себе істинного. Територіальна «вузькість», геометричне обмеження в «Романі юрби...» компенсується широкими часовими рамками $(1972$ - 1991), що охоплюють долі мешканців нібито безперспективної вулиці, великою кількістю персонажів, кожен 3-поміж яких - то цілий окремий світ.

Дослідники окреслюють семіопростір Шевчукової околиці (де топос околиці - знак маргінальної культури) від людини околиці до духовного маргінала [Див.: 2]. Топос околиці постає у В. Шевчука не тільки осередком маргінальної культури/свідомості, а й генератором смислів - у такому разі він корелює не стільки зі своєрідним хронотопом, географічно-антропологічним маркером, скільки наближається до «смислового обрамлення світу міста» (М. Карповець). При цьому «окраїнність» (передмістя) здобувається на широку амплітуду маркувальних геоантропологічних топосів, як-то поріг дому/помешкання, міст/межа між сакральним/профанним світами, своєрідне як табу, що визначає систему антропологічних координат і т. д. Уже сам межовий топос окраїни/передмістя передбачає місце перебування як специфічного роздвоєння, місце вибору між двома типами культури, моделями поведінки тощо. Людина значно щільніше «вмонтована» в «окраїнний» простір, оскільки околиця (передмістя) зазвичай нею «переживається» екзистенційно (як місце народження/смерті, самоідентифікації, тіснішої, ніж у місті, комунікації, сказати б, тотального спілкування, меншої міри відчуження і т. д.), тому це середовище має всі ознаки антрополого-екзистенційного й формує відповідний психоповедінковий стереотип, ментальний комплекс. Однак саме топос околиці (передмістя) постає у прозі Шевчука центром даного людині Богом буття, Кастальським джерелом, серединністю/ межею між сакральним/профанним, своєрідним аксіологічним буфером, переходом від однієї поведінкової моделі до іншої, межею між своїм/ чужим, духовним/тілесним, що визначає ціннісні координати, формує стереотипи спілкування, форми вибору між добром/злом. У В. Шевчука топос околиці маркується як географічно, так i метафорично (напр., топологічна метафора «стежка в траві», «дім на горі» тощо). Топос окраїни хоч і постає автономним урбаністичним i антропологічним, до певної міри замкненим часопростором, має спільні 3 містом (типові) ритуали, через проекцію яких розкриваються людські характери. Однак вона не завжди дорівнює топосу передмістя - останній несе значно більше урбаністичних конотацій, «змішаних» типажів і ситуацій. Герої Шевчукових творів - i віковічні посельці цієї околиці, й недавні переселенці з села, а саме: люди, які вже відживають своє (оповідання «Дім», «Хміль»), інтелігенти 3 поколінь (герої повісті-балади «Дім на горі», Мирослава 3 «Крику півня на світанку»), інтелігенти в першому поколінні (Віктор 3 «Крику півня на світанку»), робітники, які працюють на підприємствах у місті, але живуть у передмісті в так званому приватному секторі, а також люмпени міської околиці («П’ятий номер» 3 житомирської саги «Стежка в траві»). Звертання письменника до цієї лакуни пояснюється не тільки тим, що він сам родом із отакої околиці (з роду шевців та 
столярів) і засадничо постановив писати про те, що достеменно знає і в цьому вбачає свій естетичний керунок, а головно тим, що про таке коло людей в сучасній українській літературі другої половини минулого століття ніхто не писав.

Окрім антрополого-соціовекторних топосів, поетика В. Шевчука насичена й т. зв. «рухомими» топосами, чільним 3-поміж яких є топос дорогu, адже людина у його творах - завжди в дорозі (топос дороги виступає ще й символом, наскрізною метафорою, архетипом, бароковим концептом), завжди у пошуку: себе, істини, сенсу буття. Топоси у творах В. Шевчука набирають різних просторових (і відповідно смислових) конфігурацій. Так, замкнений простір тут - це острів, як, скажімо, у В. Голдінга («Повелитель мух», «Злодюжка Мартін», де традиційний, як у попередньому творі, топос острова звужується до топосу голої скелі, на якій гине герой), - ідеться, зокрема, про повість «Птахи з невидимого острова», або обнесений мурами монастир (роман «На полі смиренному», повість «Початок жаху»), або топос дому - як ще локальніша змодельована територія, де відбуваються найважливіші події, покликані розкрити авторську ідею, як-то в романі-баладі «Дім на горі», сама назва якої вказує на просторову обмеженість того художнього «лабораторного майданчика». Біблійні мотиви в творчості Вал. Шевчука, сконденсовані в поняттях гріха/спокути, провини, любові, блудного сина, біблійного вогню, біблійних юнаків тощо увиразнюються символічними бароковими топосами, як-то коло, сад, лабіринт, безодня, око тощо: так, традиційне для барокової антропології уявлення про «самість» людини як кулю, сферу, коло, німб святого трансформується в письменника в символічні образи Ока Прірви, розсіченого кола, черева апокаліптичного звіра - вони маркують характерну для барокового світопорядку ідею «антитетичного розламу світової гармонії» (О. Солецький). Так, топос сфери (кола), актуалізований письменником ще в ранньому періоді творчості як відповідність космогонічному сприйняттю буття, «пізній» В. Шевчук, трансформуючи вчення Г. Сковороди про «світ видимий і світ невидимий», образно розгортає в багатозначну емблему «розсіченого кола» («Розсічене коло», 1999) як еквіваленту життя в його дуалістичному наповненні, де топос розсіченого кола розгортає темпорально-топологічну спіраль людського буття.
Подібним методом творення власної художньої «Йокнапатофи» користується й Володимир Дрозд. Однак, внутрішній конфлікт між позицією митцясамітника, відгородженого від перипетій зовнішнього світу у башті зі слонової кістки (в реальності це був «халеп'ївський рай» - сільська хата-дача в мальовничому селі Халеп'я, де народилося чи не найбільше творів письменника), та соціальною заангажованістю, «розчиненням» у колективному середовищі та його потребах (займані посади у різних творчих структурах) змінює оптику бачення художнього часопростору, окреслену дещо іншою парадигмою топосів. Певна міра автобіографічного «допуску» до художньої структури твору дозволяє письменникові різною мірою абстрагуватися від внутрішнього «Я», змінювати фокус бачення загальних проблем соціуму через призму рефлексивного персонажа. Безперечно, спільне буття залишає «відбитки загальнотипового, урівнюючи індивідуальності. Міметизм соціального вторгається в приватне життя людини, але в людському протистоянні цьому антропологічне нівелювання й асиміляція (соціальна топіка) починають відтворюватися 3 урахуванням його особистісних рис і якостей» [6, с.177]. Тому за всієї типовості персонажів В. Дрозда вони не зливаються в одне суцільне «обличчя зла», а зберігають свою психологічну неповторність й упізнаваність навіть у середовищі собі подібних.

Звідси - такий калейдоскоп «масок», що розгортають ідею соціальної мімікрії та індивідуального пристосуванства, що зазвичай межує зі зрадою «істинній людині» в собі самій. Ніби граючись, В. Дрозд жонглює масками/ролями, спостерігаючи за метаморфозами своїх колоритних персонажів. Амплітуда топосів у цьому «карнавалі масок» В. Дрозда надзвичайно широка - від топоcy трибуни, обмеженого надзвичайно локальним простором, - до всеосяжного топосу украӥнського Полісся. Топос трибуни корелює у письменника насамперед 3 особистісною ідентифікацією, а саме, 3 «портфельною хворобою» («Балада про Сластьона»): устами односельців уже покійного Йосипа Сластьона він створює трагікомічну картину гіпертрофованого самолюбства й чиношанування колись звичайного селянина, котрий запродав свою душу дияволу заради ілюзії «потрібності» й жадоби слави. Маска усім «потрібної людини» приростає до нього настільки, що перетворює його на носія манії величі місцевого масштабу й після усунення з «високої» посади він не покидає 
облюбованої трибуни: тільки тепер встановлює іiі вдома й забезпечує собі «оплески» бодай в особі власної дружини. І навіть після відходу в інші світи Сластьон претендує на «верховного» трибунаоратора, котрий повчає з небес своїх односельців. Просторова ідентичність героя замикається у вузькі межі топосу трибуни, дозволяючи моделювати відповідні характери. Так створюється специфічний мандрівний топос, що набуває гіпертрофованих форм й апелює не стільки до зовнішньо-просторових, скільки до внутрішньо-психологічних маркерів: спостерігаємо іронічно-саркастичний дискурс «скидання масок» письменником зі своix персонажів, вражених хворобами соціуму. Цю тему поглиблює повість «Маслини. Історія однієї душі», що прямо вказує на внутрішні, психологічні колізії, душевні метаморфози самоідентифікації героя. Солодкий життєвий успіх маркований у свідомості героя повісті смаком маслин як своєрідним атрибутом «вищості», який став у селі символом, «поняттям широким, збірним, все одно, що вершки спивати» [3 с. 80]. «Маслинова спокуса» виступає тут аналогом ексклюзивного варіанту життя - «начальницького», красивого, «вищого». Приміряння соціально владних масок героями творів, керованих непереборним бажанням бути «над» (іншими людьми, ситуацією, обставинами, моральними приписами, зрештою, забезпечити собі вирізнення з маси й відповідні умови життя), дає необмежені можливості творити різні варіації соціальних топосів.

Вузькомарковані топоси у В. Дрозда зазвичай розгортаються в амбівалентному просторі топосів міста/села. Тож особливо гротескно, але водночас і болісно звучить у його творчості тема роздвоєння свідомості між звичним патріархальним світом українського села й новим, урбанізованим простором, де герой зазвичай шукає можливості самореалізуватися. Так, головний герой «Ирію» Михайло Решето в селі виношує мрії про місто, а в місті ностальгує за селом. Такою ж амбівалентністю позначений i Андрій Шишига 3 повісті «Вовкулака» («Самотній вовк»), котрий намагається «вичавити» 3 міста максимум власних вигод, однак у гонитві за примарним матеріальним щастям зазнає морального краху й душевного спустошення. У «Маслинах» автор нібито проводить демаркаційну лінію між метушливою зоною міста, що маркується в його свідомості гримотінням шухляд канцелярських столів, і спокійною гармонійністю предковічного села. Тож куплена героєм люлька у вигляді Мефістофеля стала наче перекидним місточком між містом/селом, адже, з одного боку, нагадувала сивих сільських дідуганів із рідних країв, котрі курять лише люльки, а з другого, у проникливому погляді Мефістофеля «було щось філософське, інтелектуальне...» [3 с. 92]. Цей водорозділ між містом/селом, болючий для багатьох персонажів творів В. Дрозда, маркується різними художніми засобами: пейзажем з його багатоманіттям «живих» топосів, що промовляють «устами» природи, розмаїттям предметної атрибутики (трибуна, шухляда, портфель і т. д.), специфічним портретуванням, а головне - внутрішніми переживаннями, ситуативною настроєвістю, емоційно забарвленою несилуваним ліризмом або ж урбанізованою агресивністю, яка часом пом'якшується ностальгією за тим, що живе хіба що в спогадах деформованої душі. Зрештою, «запах паперів ніколи не заступить для людини віковічного запаху зораної землі» [3, с. 84]. Проте місто також може відкритися справжнім своїм «обличчям» як величне в своїй «замисленій тисячолітній тиші», скинувши свою метушливу «базаркувату маску». I тоді герой твору може досягти бажаної гармонії, подолавши ті соціальні дисонанси, що виповнюють його душу часто неусвідомленим почуттям невдоволення від життя.

Суб'єктивізація внутрішнього часопростору, передана за допомогою внутрішнього мовлення героя, виопуклює - через виразну, промовисту деталь, спроектовану на різні моделі владних топосів - траєкторію суспільного зламу, що спричиняє метаморфози повсякденної свідомості. За рахунок цього проекція соціальних катаклізмів і деформацій на внутрішній «екран» рефлексивної особистості дає незвичайний ефект достовірності й переконливості. Тож автобіографічність, яка має як внутрішній, так і зовнішній вимір, і межі якої встановлює сам В. Дрозд згідно зі своїми уявленнями про міру допуску свого alter-ego у мистецький твір, дозволяє письменникові глибоко зануритися у внутрішній світ героя, використати максимальну дозу нищівної іронії й самоіронії тощо, що убезпечує від зсуву художньої свідомості у бік зумисної ідеалізації. Письменницьке перевтілення як данина специфіки психології творчості само собою передбачає своєрідну «гру масок» - у межах правил, визначених природою таланту i самим митцем: вони виокреслюють соціально-індивідуальний простір твору, його психологічні інтенціï, зони впливу на читача тощо. Тема «маски» в його творчості виходить поза межі психології творчості, i цей другий рівень «перевтілення», використовуючи розроблену письменником власну систему топосів, 
продиктований проблематикою пристосуванства людини в нездоровому соціумі. Адже тенденції пристосуванства передбачають постійну зміну соціальних масок, таких, що зазвичай «грають» на публіку, забезпечуючи їх носіям прихильність тих, хто встановлює «правила», а відтак і належне матеріальне забезпечення. Метаморфози сучасної людини як носія соціальних масок (маски людини-портфеля, маска вічного трибуна 3 активно діючим топосом трибуни, маска невмирущого начальника, маска блазня, маска успішної людини, маска генія і т.д.) та поглиблення антропологічної мімікрії перед «лицем соціуму» зрештою дає можливість зрозуміти, що «...обман перед «незрячими» очима іншого обертається обманом власних очей» [4, с.189]. Така облудність пошуку нібито успішності за рахунок компромісу із власною совістю завжди призводить героїв В. Дрозда до краху, який усвідомлюється ними як втрата самих себе, втрата в собі чогось первозданного, що практично неможливо ні регенерувати, ні «відкупити» у долі найщемливішими спогадами про «золотий вік» дитинства 3 його топосом втраченого раю, на повернення в яке остаточно втратив моральне право. Цю тему письменник символічно заклав у своїй творчості одним із ранніх своїх оповідань «Білий кінь Шептало» (однойменна збірка 1969 р.), де проблема уніфікації людини, нівеляції, роздвоєння й пристосуванства психологічно глибоко й майстерно подана крізь призму «долі» й сприйняття гордого білого коня Шептала, якому обставини диктують необхідність прикидатися сірим - таким, як інші.

Однак є й інший бік творчості В. Дрозда: це моделювання ним топосу малої батьківщини 3 максимально можливими проекціями на велику Україну як своєрідне дзеркало всіх типів «локальних» ментальностей 3 їхніми різновидами смислоформуючих топосів. На противагу вигаданій Йокнапатофі В. Фолкнера роман-епопея В. Дрозда «Листя землі», що став значною віхою у його творчості, окреслює топонім реальної місцевості Сіверського Полісся з його особливим психотипом людини, чиї геопсихологічні особливості значною мірою визначають і ії долю в розрізі загальнонаціональної еволюції. Власне, вся творчість В. Дрозда - це пошуки землі обітованої, втіленої ним у топоci рідного Краю під іменем Пакуль (маленьке село у Чернігівській області), тяжіння до якого письменник задекларував ще в повісті «Ирій» устами Михайла Решета, фактично ототожнюючи топос Пакуля з топосом ирію, до якого завжди поривати- меться людська душа, аби потім зриватися звідтіль у широкі світи. Так топос рідного Краю корелює 3 біблійним мотивом про блудного сина, який завжди повертається до рідного порогу (i топос порогу тут також $є$ визначальним), аби, повернувшись, знову вирушати у великий світ. Такі просторово-часові метаморфози наповнюють топоси особливими буттєвими сенсами, витворюючи особливі параметри й маркери тієї міфологічної моделі, яку творить письменник у межах рідного Сіверського Полісся.

Особливості індивідуальної й колективної самоідентифікації в романі «Листя землі» передано «голосами» реальних людей, записаних письменником i відтворених на сторінках твору як своєрідні монологи, виділені при цьому в тексті курсивом (чи можемо говорити тут про фіксований на папері, графiчний топос голосу?). Це розгорнутий у слові міф про пошуки поліською людиною топосів втраченого раю, землі обітованої, символом яких постає земля Горіхова (висока й світла ілюзія Гаврила Латки) - як топос благодатного краю, делюдина маєможливість бути самою собою, вдивлятися в «обличчя» природи як у дзеркало, пізнаючи вищі, гармонійні закони співіснування світу природного й світу людського. Космогонічний міф про Пакуль як сакралізований центр міфологічного топосу Краю розгортається у творі 3 допомогою зміщення часово-просторових площин, різних проекцій тих самих подій, що створює ефект циклічності, використання біблійних символів (Бог, Богоматір як «матір дітей людяцьких», Божий суд, топоси раю, пекла, райського саду тощо), глибоких християнських паралелей й водночас відчутної пантеїстичної наснаженості, що живить глибоке письменницьке розуміння природи як живої складової людського світу. Система міфології прочитується в романі на кількох рівнях: символіки топосів, способу організації та структури тексту, моделювання характерів тощо. Вже сама назва твору «Листя землі», що несе біблійний код, дешифрує складну символіку твору: сезонно-циклічна метафорика образу листя означає зміну, оновлення - через процес руйнації, оновлення й невмирущість роду й родоводу. А ще - єдність землі і неба, той метафізичний часопростір, де й накопичується людський дух. Все це, відповідно, розгортає ціле віяло топосів сезонності. Міфологічний часопростір зазвичай характеризується циклічністю: події повторюються, подаються 3 точки зору різних оповідачів, що надає цим подіям стереоскопічності, особливої глибини, ймовірнісної множинності, час втрачає лінійність. Відтак людська доля постає в різних проекціях, розкриває не тільки 
свою реальну іпостась, а й потенційну, закладену в природі людини, але не спроможну зреалізуватися в жорстких умовах історичних потрясінь. Використана автором циклічна замкнутість параболічно несе в собі ідею вічного оновлення, відродження, невмирущості народу. У творі немає побічних, маргінальних сюжетів: усі вони рівнозначні, магістральні, а переплетеність доль героїв подається через пов'язаність сюжетних ліній. Вузол сюжетних ліній творить своєрідний сугестивний фокус, у якому час нібито уповільнюється, повертаючи до читача - через апробовану систему топосів - різні грані людської долі й недолі, вияскравлюючи таким чином характери численних героїв, кожен 3-поміж яких несе власний код прочитання історії людської душі. Також це глибока проекція того, як має еволюціонувати суспільство, щоб на цьому шляху було якомога менше людських i моральних втрат, породжених злом як втіленням недосконалості людської природи.

Окремою важливою темою в творчості письменника залишається філософія влади: у В. Дрозда це завжди сила, що маніпулює людиною, спричиняючи руйнівні трансформації у людській душі, яка не завжди здатна чинити опір метафізиці влади. Потужно розгортається в романі «Листя землі» й тема зрадництва, що має свої модифікації - відступництва, продажності. Письменник виводить причину цього ганебного явища від психологічного феномену страху, який підточує моральні засади людини, руйнує її цілісність. Однак це також трансформація біблійного мотиву відступництва, до якого В. Дрозд звертався вже в ранній творчості. Так, в оповіданні «Іскаріот» (написане 1972 р., уперше надруковане 1990) спостерігаємо накладання семантики євангельського образу на життєподібні ситуації й колізії, де акт зради набуває онтологічної множинності в контексті мотиву «постійного воскресіння Іуди, який ніби мандрує в часі і простоpi i змушений попри свою волю і бажання вершити євангельське діяння» [1, с.195]. Саме таку темпоральну проекцію в розрізі столітнього буття української людини подає автор у «Листі землі», виводячи 3 цього криву національних негараздів і втрат. Утілення зла в діяннях людських у їхній дорозі до побудови ілюзорного земного раю (ідеалізований топос недосяжності) розкривається через криваві злочини сталінського тоталітаризму. У цій площині особливої ваги набирає ціна людського життя у вимірі історичного поступу - іiї письменник виважує на терезах совісті та родового обов'язку перед нащадками, що допомагає залучити читача до активного діалогу з письменником, 3 власною та колективною пам'яттю.

Бінарні опозиції (життя/смерть, любов/ненависть, відданість/зрада, доброчинність/гріховність i т. п.) несуть в романі не ідею протистояння, а ідею взаємозумовленості, втіленій у авторській концепції добра/зла як сув'язі взаємообернених, але й взаємозумовлених понять, відповідно, формують і систему аксіологічно забарвлених топосів. Перед читачем постає ціла галерея героїв твору, наділених міфологічною свідомістю, в якій закодовані архетипні первні, онтологічні цінності і моральні константи, «просвічені» через систему вивірених топосів, чільним 3-поміж яких залищається топос утраченого раю. Варіативність доль, крізь які зримо проглядаються всі етапи російської, а потім радянської імперії і мозаїка яких витворює панораму буття української людини з широким розгалуженням топосів, - це те поле художньо-психологічного дослідження, яке підносить В. Дрозда до рівня літописців своєї доби. Адже «Листя землі» нагадує «велетенської довжини сувій білого полотна (ще один дотичний топос - сувій полотна - Л.Т.), розстеленого на березі вічної ріки життя. I кожен, хто 3'явився на цей світ Божий, у цей жорстокий і ніжний, грішний і праведний світ, ступає босими ногами на цей білий сувій національної долі й залишає на ньому свій слід...» [5, с 30].

Отже, $з$ допомогою поетики локального простору цим прозаїкам вдалося художньо відтворити візію України у іiі розмаїтих часопросторових векторах, спроектувати «колективний портрет» української людини з іï самобутньою ідентичністю. Наративи «малої батьківщини» українських письменниківшістдесятників: житомирський текст Валерія Шевчука та поліський текст Володимира Дрозда - 3 їхніми топосами, геоментальними моделями, проекціями на «образи свідомості» моделюють художню топографію топосів метафоричного наповнення «землі обітованої», «Кастальського джерела», «втраченого раю» (через розгортання вектору сім'я/родина - оселя/дім - вулиия/юрба - околиия/передмістя/ місто, дорога, ключовим у якому є топос дому), які вибудовують модель сприйняття світу й себе у цьому світі. Художня репрезентація національної ідентичності у іiі регіональних варіантах як локальної автентичності, спроектованої на візію «великої України» (колективна та індивідуальна ідентичність у її соціокультурних виявах) дає перспективи дослідження етно-національних текстових проекцій ідентичностей у художньому дискурсі. 


\section{СПИСОК ВИКОРИСТАНИХ ДЖЕРЕЛ:}

1. Антофійчук В. Євангельські образи в українській літературі XX століття: Монографія/Володимир Антофійчук. Чернівці: Рута, 2001. - 335 с.

2. Городнюк Н. Знаки необарокової культури Валерія Шевчука: Компаративні аспекти»/Наталя Городнюк. Київ: Твім інтер, 2006. - 216 с.

3. Дрозд В. Маслини. Історія однієї душі/Володимир Дрозд//Вітчизна. - 1967. - №2. - С. 72-105.

4. Ильин В. В. Философская антропология: учебное пособие / В. В. Ильин. - М.: КДУ, 2006. - 232 с.

5. Жулинський М. На самотині з Богом/Микола Жулинський// Володимир Дрозд. Листя землі. Книга I. Упорядник Ірина Жиленко/Бібліотека

\section{REFERENCES:}

1. Antofijchuk V. Yevanhel's'ki obrazy v ukrains'kij literaturi KhKh stolittia: Monohrafiia/Volodymyr Antofijchuk. Chernivtsi: Ruta, 2001. - 335 s. (in Ukrainian).

2. Horodniuk N. Znaky neobarokovoi kul'tury Valeriia Shevchuka: Komparatyvni aspekty»/Natalia Horodniuk. Kyiv: Tvim inter, 2006. - 216 s. (in Ukrainian).

3. Drozd V. Maslyny. Istoriia odniiei dushi/Volodymyr Drozd//Vitchyzna. - 1967. - №2. - S. 72-105. (in Ukrainian).

4. Yl'yn V. V. Fylosofskaia antropolohyia: uchebnoe posobye / V. V. Yl'yn. - M.: KDU, 2006. - 232 s. (in Russian).

5. Zhulyns'kyj M. Na samotyni z Bohom/Mykola Zhulyns'kyj// Volodymyr Drozd. Lystia zemli.
Шевченківського Комітету. - К.: Видавничий дім «Києво-Могилянська академія», 2009. - С. 8-35.

6. Кузин И. Маски субъекта: Стратегии социальной идентификации/И. В. Кузин. - СПб: Издво Санкт-Петербургского университета, 2004. $-310 \mathrm{c}$.

7. Мінаков М. А. Історія поняття досвіду // Михайло Мінаков. - К.: ПАРАПАН, 2007. - 380 с.

8. Тарнашинська Л. Художня галактика Валерія Шевчука. Постать сучасного українського письменника на тлі західноєвропейської літератури / Людмила Тарнашинська. - К.: Вид-во ім. Олени Теліги, 2001. - 224 с.

Knyha I. Uporiadnyk Iryna Zhylenko/Biblioteka Shevchenkivs'koho Komitetu. - K.: Vydavnychyj dim «Kyievo-Mohylians'ka akademiia», 2009. - S. 8-35. (in Ukrainian).

6. Kuzyn Y. Masky sub'ekta: Stratehyy sotsyal'noj ydentyfykatsyy/Y. V. Kuzyn. - SPb: Yzd-vo Sankt-Peterburhskoho unyversyteta, 2004. - 310 s. (in Ukrainian).

7. Minakov M. A. Istoriia poniattia dosvidu // Mykhajlo Minakov. - K.: PARAPAN, 2007. - 380 s. (in Ukrainian).

8. Tarnashyns'ka L. Khudozhnia halaktyka Valeriia Shevchuka. Postat' suchasnoho ukrains'koho pys'mennyka na tli zakhidnoievropejs'koi literatury / Liudmyla Tarnashyns'ka. - K.: Vyd-vo im. Oleny Telihy, 2001. - 224 s. (in Ukrainian).

\title{
"YOKNAPATAWPHA" BУ VALERIY SHEVCHUK AND VOLODYMYR DROZD AS A TOPOS OF "LOST PARADISE": MODELING OF A "SMALL HOMELAND"
}

\author{
Liudmyla Tarnashynska \\ tarnashynska@gmail.com \\ Doctor of Philology hab., Professor, Leading Researcher, T. Shevchenko Institute of Literature, \\ National Academy of Sciences of Ukraine
}

\begin{abstract}
The researcher focuses on the narratives of the "small homeland" (with projections on world literature) of Ukrainian writers of the sixties: the Zhytomyr text by Valeriy Shevchuk and the Polissya text by Volodymyr Drozd with their topoi, geomental models, and projections on "images of consciousness." It is an artistic topography of topoi of metaphorical filling of the "Promised Land," "Castalian Spring," "lost paradise" (through the deployment of the vector family - house/home - street/crowd - neighborhood/suburb/city, road, in which a home topos is a key one), which build a model of perception of the world and oneself in this world.

The focus of research is an artistic representation of national identity in its regional versions as a local authenticity projected on the vision of "Greater Ukraine" (collective and individual identity in its socio-cultural manifestations). This makes it possible to explore ethno-national textual projections of identities in artistic discourse. Researcher traces how, with the help of the poetics of local space, these prose writers managed to artistically recreate the vision of Ukraine in its various space-time vectors, to design a "collective portrait" of a Ukrainian person with her/his original identity.
\end{abstract}

Key words: Yoknapatawpha; "lost paradise;" topos; Zhytomyr text; Polissya text; identity. 